\title{
THERMAL CHARACTERISTICS AND ELECTRICAL PROPERTIES OF HOT DEFORMED AA7075 ALLOYS WITH AND WITHOUT Sc, Zr ADDITIONS
}

\author{
Veronika KODETOVÁ, Martin VLACH, Michal LEIBNER, Hana KUDRNOVÁ, Petr HARCUBA, \\ Lucia BAJTOŠOVÁ, Miroslav CIESLAR
}

\author{
Faculty of Mathematics and Physics, Charles University, Prague, Czech Republic, EU, \\ veronika.kodetova@seznam.cz
}

https://doi.org/10.37904/metal.2020.3601

\begin{abstract}
In the present work AA7075 alloys with and without Sc, Zr addition after hot deformation were studied. Thermal responses of precipitation reactions of hot deformed alloys were studied by differential scanning calorimetry, the relative electrical resistivity changes were determined by DC four-point method. The interconnections of these two materials characteristics were presented. Thermal and electrical measurements were compared to microstructure development that was observed by scanning and transmission electron microscope. Two types of eutectic phase were proved at (sub)grain boundaries. In the AA7075-Sc,Zr alloy primary multilayer $\mathrm{Al}_{3}(\mathrm{Sc}, \mathrm{Zr}$ ) particles precipitated during casting and subsequent cooling. In the thermal curves one exothermic process at $\sim 200{ }^{\circ} \mathrm{C}$ and the decrease of relative resistivity changes were observed. Apparent activation energy of this process was calculated using by Kissinger method as $\sim 100 \mathrm{~kJ} / \mathrm{mol}$ regardless Sc, Zr addition. Schematic timetemperature-transformation diagram of the exothermic process was done on the base of calorimetric measurements at different heating rates.
\end{abstract}

Keywords: Al-based alloys, hot deformation, differential scanning calorimetry, electrical resistometry

\section{INTRODUCTION}

The AA7075 based alloys (AIZnMgCu) are widely used in metalworking and aerospace industries, e.g. Refs. [1-4]. These alloys are particularly interesting due to their excellent strength, ductility, high toughness or resistance to stress corrosion cracking and damage tolerance [1-5]. Processing (like solution treatment, quenching or ageing), appropriate alloying, or a combination of both can be a good tool for controlling most of these properties.

Two decomposition sequences of $\mathrm{AIZnMg}(\mathrm{Cu})$ based alloys are known [6-8]: a) supersaturated solid solution $(\mathrm{SSS}) \rightarrow$ solute clusters/Guinier-Preston (GP) zones $\rightarrow \eta^{\prime}$ phase (hexagonal structure) $\rightarrow \eta$ phase $\left(\mathrm{MgZn}_{2}\right.$, hexagonal structure), b) SSS $\rightarrow$ solute clusters/GP zones $\rightarrow T^{\prime}$ phase (hexagonal $\left.\mathrm{Al}_{2} \mathrm{Zn}_{3} \mathrm{Mg}_{3}\right) \rightarrow T$ phase (cubic $\mathrm{Al}_{2} \mathrm{Zn}_{3} \mathrm{Mg}_{3}$ ). The precipitation sequence could be more complicated, the formation of metastable precipitates depends on the alloy composition, artificial ageing temperature, ageing time, heat treatment etc. [6-9]. It turns out that the precipitation sequence also highly depends on ratio of $\mathrm{Zn}$ and $\mathrm{Mg}$ addition [7].

In most cases, $\mathrm{Sc}$ is an effective admixture which can improve the strength, inhibit recrystallization and also refine grains [1]. When the content of Sc is increased from 0 to $0.6 \mathrm{wt} \%$ then the hardness and also tensile and yield strength increase but there could be a problem with a loss in ductility [10]. The reason why Zr together with Sc are used as admixtures is the lower price of final alloys nevertheless the mechanical properties are comparable to the alloys with only Sc addition [1]. The addition of $2 \mathrm{wt} \%$ of $\mathrm{Zr}$ to Al alloys $7 \mathrm{xxx}$ series also leads to the reduction of size of grains (from 1500 to $190 \mu \mathrm{m}$ ) [5]. The improvements of mechanical properties of the alloys with both $\mathrm{Sc}$ and $\mathrm{Zr}$ additions are caused by the precipitation of the secondary $\mathrm{Al}_{3}(\mathrm{Sc}, \mathrm{Zr})$ particles with $\mathrm{L}_{1}$ structure $[1,11]$. The $\mathrm{Al}_{3}(\mathrm{Sc}, \mathrm{Zr})$ phase is more stable at higher temperatures than the $\mathrm{Al}_{3} \mathrm{Sc}$ and/or 
$\mathrm{Al}_{3} \mathrm{Zr}$ phase and also has a distinctive hardening effect $[1,11,12]$. Primary intermetallic particles $\mathrm{Al}_{3} \mathrm{Sc}$ and/or $\mathrm{Al}_{3} \mathrm{Zr}$ and/or $\mathrm{Al}_{3}(\mathrm{Sc}, \mathrm{Zr}$ ) were observed in the cast ingots with Sc, $\mathrm{Zr}$-additions [13-15]. These particles are rectangular, triangular and/or polygonal with dimension about 2-5 $\mu \mathrm{m}$ and mostly appear inside (in the centre of) the grains [13-15]. These particles in $\mathrm{AlZnMgCu}$-based alloys consist of layers $\mathrm{Al}_{3}(\mathrm{Sc}+\mathrm{Zr})+\mathrm{a}-\mathrm{Al}+$ $\mathrm{Al}_{3}(\mathrm{Sc}+\mathrm{Zr})+\alpha-\mathrm{Al} \ldots[$ [13-15].

\section{EXPERIMENTAL DETAILS}

Two (in wt\%) Al-6.6Zn-3.0Mg-1.9Cu-0.2Fe (AlZnMgCu) and Al-6.2Zn-2.9Mg-1.8Cu-0.2Fe-0.23Sc-0.19Zr (AIZnMgCuScZr) alloys were isothermally annealed at $300^{\circ} \mathrm{C} / 60 \mathrm{~min}$ and then hot deformed with reduction of $5 \%$ (HR5) and $10 \%$ (HR10). Hot deformation of the alloys was done on motorized single rolling mills type MDM LS120. The degree of deformation was manually adjusted within an accuracy of $0.1 \mathrm{~mm}$. Constant rolling speed $4 \mathrm{~m} / \mathrm{min}$ was used. A high temperature hot plate PZ38-3T with temperature controller was used for heating of the alloys. Immediately after heating, the alloys were hot deformed and process was finished by quenching into water at room temperature (RT). The entire hot deformation process will not take longer than 10 seconds.

The relative electrical resistivity changes $\Delta \rho / \rho_{0}$ was measured at $78 \mathrm{~K}$ by DC four-point method. The effect of parasitic thermoelectromotive force was restrained by current reversal. Vickers microhardness (HV) was determined at RT on polished samples. Differential scanning calorimetry (DSC) was used for the study of the thermal behaviour of the alloys. Measurements were performed at heating rates of $1-30 \mathrm{~K} / \mathrm{min}$ in the Netzsch DSC $204 \mathrm{~F} 1$ Phoenix apparatus with $\mathrm{Al}_{2} \mathrm{O}_{3}$ crucibles. The mass of the samples was between $10-20 \mathrm{mg}$ and nitrogen flow of $40 \mathrm{ml} / \mathrm{min}$ was used as a protective atmosphere.

The development of microstructure was investigated by transmission and scanning electron microscopy (TEM and SEM). JEOL JEM 2000FX, FEI Quanta 200FEG and MIRA I Schottky FE-SEMH microscopes were used. Energy-dispersive spectroscopy (EDS) was carried out using by X-ray BRUKER microanalyser.

\section{RESULTS AND DISCUSSION}

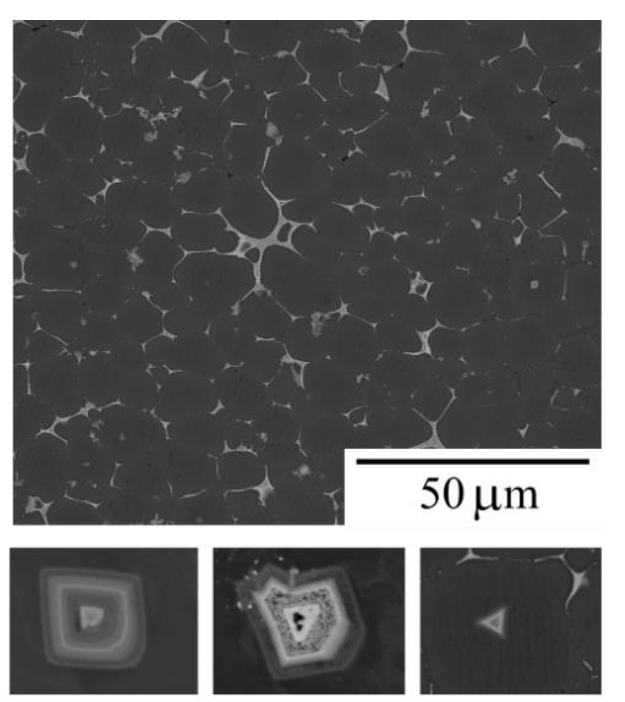

\section{$5 \mu \mathrm{m}$}

Figure $1 \mathrm{SEM}$ image of the AlZnMgCuScZr HR10 alloy. See eutectic phase and detail of primary $\mathrm{Al}_{3}(\mathrm{Sc}, \mathrm{Zr})$ particles
Eutectic phase at subgrain boundaries in the initial state of all studied alloys was observed by SEM - see Figure 1. The volume fraction of the eutectic phase was very close for both $\mathrm{AlZnMgCu}$ and AIZnMgCuScZr alloys. Detailed TEM analysis revealed that this phase in the AlZnMgCuScZr alloy is a combination of $T$ phase $\left(\mathrm{Mg}_{32}(\mathrm{Al}, \mathrm{Cu}, \mathrm{Zn})_{49}\right)$ and $\mathrm{Mn}, \mathrm{Fe}$,Si-rich phase. Moreover, the $S$ phase $\left(\mathrm{Al}_{2} \mathrm{CuMg}\right)$ was observed in the $\mathrm{AlZnMgCu}$, too. Primary multilayer $\mathrm{Al}_{3}(\mathrm{Sc}, \mathrm{Zr})$ particles were observed inside grains in the initial state of the AlZnMgCuScZr HR5 and HR10 alloys. In the Figure 1 SEM image of the AIZnMgCuScZr HR10 alloy in the initial state is shown, one can see eutectic phase at (sub)grain boundaries and the detail of primary $\mathrm{Al}_{3}(\mathrm{Sc}, \mathrm{Zr})$ particles. The average size of primary $\mathrm{Al}_{3}(\mathrm{Sc}, \mathrm{Zr})$ particles was $2-5 \mu \mathrm{m}$ and structure of layers was identified as $\mathrm{Al}_{3}(\mathrm{Sc}+\mathrm{Zr})+\alpha-\mathrm{Al}+\mathrm{Al}_{3}(\mathrm{Sc}+\mathrm{Zr})$ $+\alpha-\mathrm{Al}+\ldots$. These results are in agreement with [13-15].

The response of microhardness HV0.5 to isochronal step-by-step annealing of the HR5 and HR10 alloys is in the Figure 2. The deformation has significant influence on microhardness values during isochronal annealing up to $450{ }^{\circ} \mathrm{C}$. Higher initial values in the AlZnMgCuScZr alloys than in AlZnMgCu alloys $(\Delta \mathrm{HV} 0.5 \approx 20$ ) 
are probably caused by presence of Sc,Zr-containing particles and/or by higher content of addition in the AlZnMgCuScZr alloy. The initial values of HV0.5 was in the same studied alloys in the as-prepared state HV0.5 $\approx 120$ for the AlZnMgCu and HV0.5 $\approx 130$ for the AlZnMgCuScZr alloy [13,15].

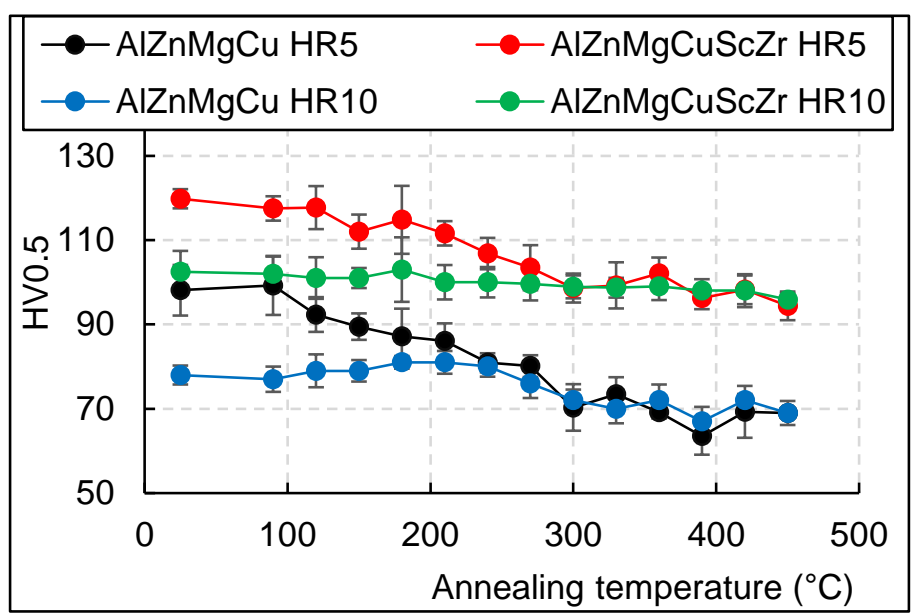

Figure 2 Isochronal annealing curves of microhardness changes HV0.5 (measured at RT) of the HR5 and HR10 $\mathrm{AlZnMgCu}(\mathrm{ScZr})$ alloys
Microhardness values of the HR5 alloys continually decrease up to annealing at $300{ }^{\circ} \mathrm{C}$. After that, the values are almost constant (in the accuracy of measurements) up to the end of the annealing at $450{ }^{\circ} \mathrm{C}$. After annealing up to $240{ }^{\circ} \mathrm{C}$ (for the $\mathrm{AlZnMgCu}$ ) and up to 300 ${ }^{\circ} \mathrm{C}$ (for the AlZnMgCuScZr) the effect of different deformation degree disappeared. The difference between values HV0.5 of the $\mathrm{AlZnMgCu}$ and $\mathrm{AlZnMgCuScZr}$ (HR5 and HR10) up to $\sim 300^{\circ} \mathrm{C}$ is $\Delta H V 0.5 \approx 20$, in the temperatures above $300^{\circ} \mathrm{C} \Delta \mathrm{HV} 0.5 \approx 30$.

Figure 3 show DSC curves of the $\mathrm{AlZnMgCu}(\mathrm{ScZr}) \mathrm{HR} 10$ and HR5 alloys at different heating rates up to $400{ }^{\circ} \mathrm{C}$. One can see significant exothermic process. The maximum of this process is shifted to

higher temperatures with higher heating rate. The addition of $\mathrm{Sc}$ and $\mathrm{Zr}$ to the $\mathrm{AlZnMgCu}$ alloy caused the small shift $\left(5-10^{\circ} \mathrm{C}\right)$ of maxima to lower temperatures, no shift was observed with different deformation degree. The activation energies of the exothermic process were calculated using by Kissinger method [16] regardless Sc, Zr addition and different deformation degree as $\sim 100 \mathrm{~kJ} / \mathrm{mol}$. Schematic time-temperature-transformation diagram (TTT diagram) of the exothermic process is shown in the Figure 4. The points corresponding to $50 \%$ volume transformation of the process are plotted against temperature versus time on logarithm scale.
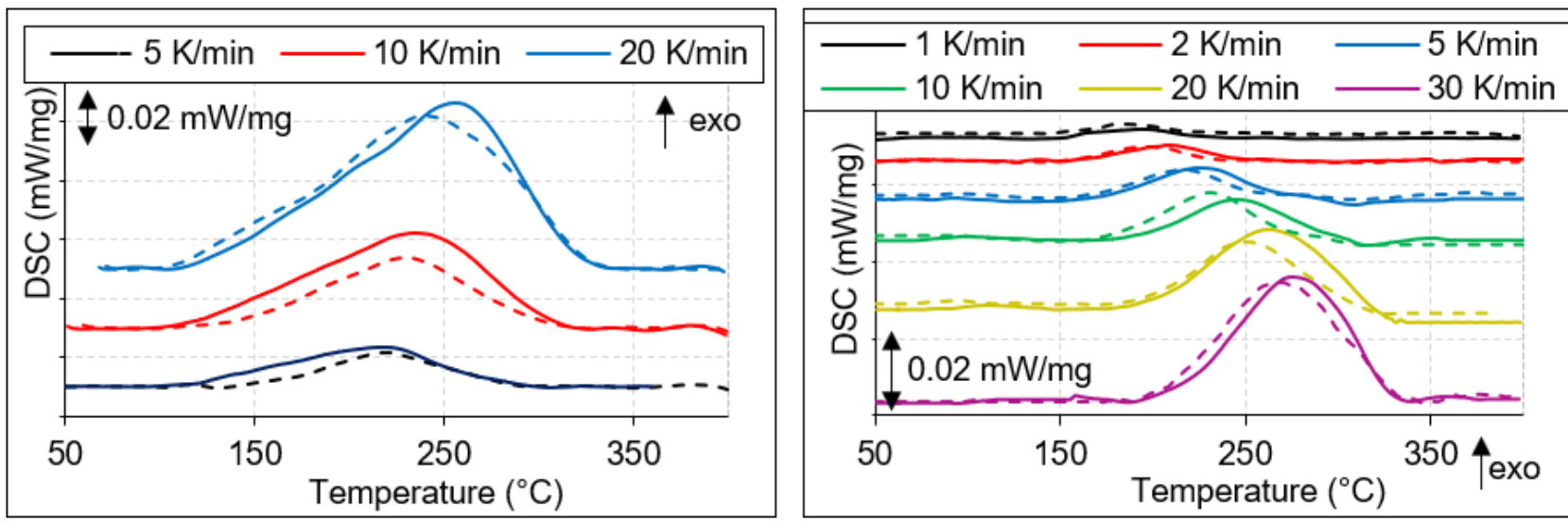

Figure 3 DSC traces of AlZnMgCu (full lines) and AlZnMgCuScZr (dashed lines) a) HR5 alloys, b) HR10 alloys, at different heating rates

Response of relative resistivity changes to step-by-step isochronal annealing of $\mathrm{AlZnMgCu}(\mathrm{ScZr}) \mathrm{HR} 10$ alloys is plotted in the Figure 5a. Electrical resistivity of both HR10 alloys decreases up to $\sim 300{ }^{\circ} \mathrm{C}$ in three stages (I-III) and after that sharply increase up to annealing up to $450{ }^{\circ} \mathrm{C}$ (IV). For a better recognition negative numerical derivative (spectrum curves) of the annealing curves from Figure 5a are shown in the Figure 5b. 
In the spectra curves one can see three positive stages (I-III) with maxima at $\sim 110{ }^{\circ} \mathrm{C}, \sim 180{ }^{\circ} \mathrm{C}$ and $\sim 250$ ${ }^{\circ} \mathrm{C}$. The maximum of the most significant II-stage is shifted to lower temperatures with $\mathrm{Sc}, \mathrm{Zr}$ addition. The first minor relative resistivity decreases and minor I-stage at spectrum curves with maxima at $\sim 110{ }^{\circ} \mathrm{C}$ is probably caused by the dissolution of GP zones and/or clusters. These results are in agreement with [13-15, $17,18]$ where dissolution of GP zones and/or clusters were observed at temperatures $100-150{ }^{\circ} \mathrm{C}$. Small decreases in microhardness values up to $150^{\circ} \mathrm{C}$ in HR5 alloys are probably connected to these. No thermal changes up to $150^{\circ} \mathrm{C}$ were observed at DSC curves of HR5 and HR10 alloys. Because of the small visibility of the I-stages in spectrum curves and no visibility in DSC curves we assume, that the amount of dissolved GP zones and/or clusters is small.

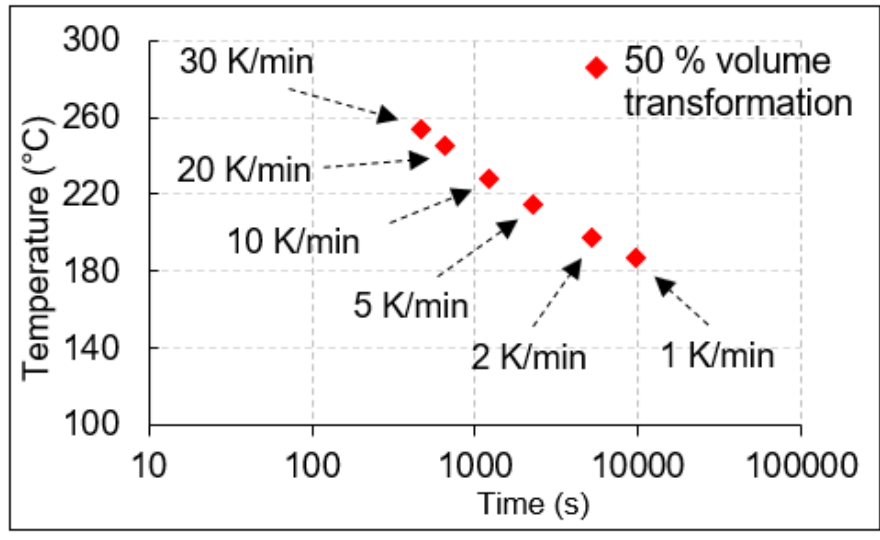

Figure 4 Schematic time-temperature-transformation diagram (TTT) diagram of the exothermic process of AlZnMgCuScZr HR10 alloy
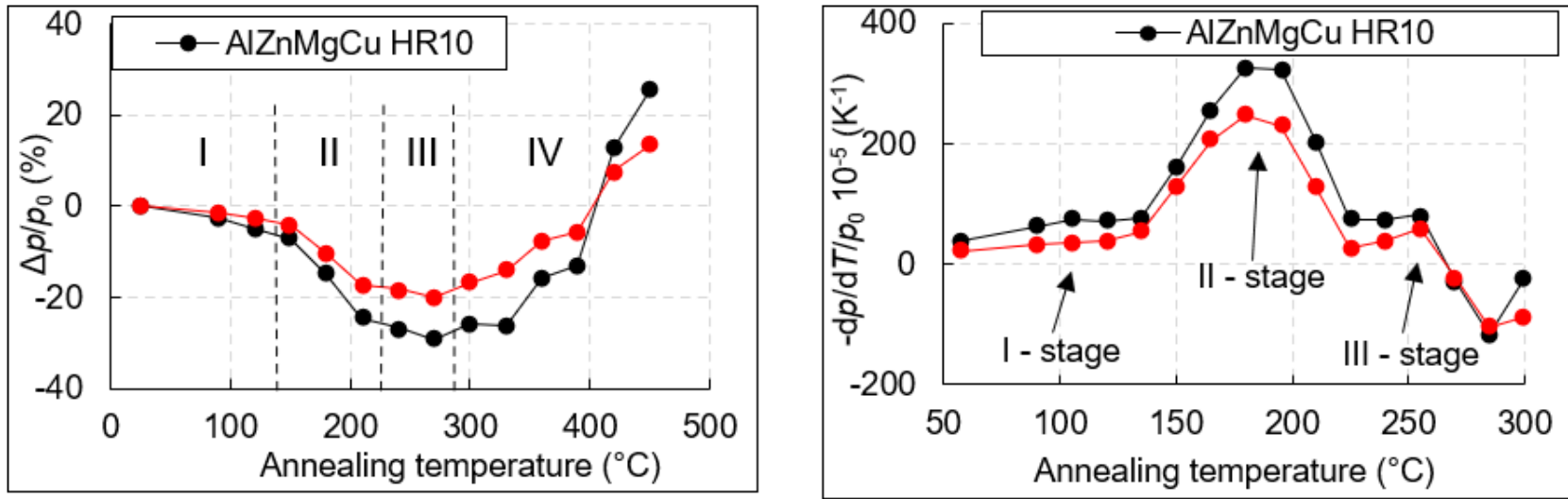

Figure 5 a) Relative resistivity changes (measured at $78 \mathrm{~K}$ ) of the $\mathrm{AlZnMgCu}(\mathrm{ScZr}) \mathrm{HR} 10$

b) spectra derived as negative derivative of resistivity curves during isochronal annealing of the $\mathrm{AlZnMgCu}(\mathrm{ScZr}) \mathrm{HR} 10$ alloys

After annealing up to $240{ }^{\circ} \mathrm{C}$ two types of particles were observed by transmission electron microscopy rounded particles of the $S$ phase $\left(\mathrm{Al}_{2} \mathrm{CuMg}\right)$ and rods of the non-eutectic $T$ phase $\left(\mathrm{Al}_{2} \mathrm{Zn}_{3} \mathrm{Mg}_{3}\right)$ [14]. The main resistivity decrease (II) and II-stage at spectrum curves with maxima at $\sim 180{ }^{\circ} \mathrm{C}$ to which exothermic processes in DSC curves (with maximum at $\sim 195^{\circ} \mathrm{C}$ at heating rate $1 \mathrm{~K} / \mathrm{min}$ in HR10 alloys) and activation energy $100 \mathrm{~kJ} / \mathrm{mol}$ correspond, together with small III-stage at spectrum curves with maxima at $\sim 250^{\circ} \mathrm{C}$ are probably caused by combination of precipitation of $T$ phase and/or precipitation and/or coarsening of $S$ phase. The microhardness values from RT to annealing up to $240^{\circ} \mathrm{C}$ of HR10 alloys (see Figure 2) show no changes (in accuracy of measurement) which leads to the conclusion that neither precipitation of $T$ phase particles nor precipitation of $S$ phase particles leads to any hardening effect. This result is in agreement with $[14,19,20]$. 
Microscopy observation after annealing up to $360^{\circ} \mathrm{C}$ proved presence of secondary $\mathrm{Al}_{3}(\mathrm{Sc}, \mathrm{Zr})$ particles in the $\mathrm{AlZnMgCuScZr} \mathrm{HR}$ alloys [14]. Although secondary $\mathrm{Al}_{3}(\mathrm{Sc}, \mathrm{Zr})$ particles was not observed in the initial state of the AlZnMgCuScZr HR alloys, on the base of microhardness values and typical hardening effect of these particles $(\triangle H V \approx 25-40[13,17,21,22])$ we assume their presence in the initial state of the AlZnMgCuScZr HR alloys, too. These particles probably precipitate during annealing at $300{ }^{\circ} \mathrm{C} / 60 \mathrm{~min}$ before/during hot deformation. After annealing up to $360^{\circ} \mathrm{C}$ additional precipitation and/or coarsening of these particles caused their clearly identification by TEM and ED. No thermal processes were observed in DSC curves of HR alloys which could correspond to precipitation and/or coarsening of the $\mathrm{Al}_{3}(\mathrm{Sc}, \mathrm{Zr})$ particles.

\section{CONCLUSIONS}

The results of characterization of hot deformed $\mathrm{AlZnMgCu}(\mathrm{ScZr})$ alloys arriving the following conclusions:

- $\quad$ Two types of eutectic phase ( $T$ phase $\left(\mathrm{Mg}_{32}(\mathrm{Al}, \mathrm{Cu}, \mathrm{Zn})_{49}\right)$ and $\mathrm{Mn}, \mathrm{Fe}, \mathrm{Si}$-rich phase) at (sub)grain boundaries in the initial state of the all alloys studied was observed. Primary multilayer $\mathrm{Al}_{3}(\mathrm{Sc}, \mathrm{Zr})$ particles were observed in the AIZnMgCuScZr hot deformed alloys.

- Higher initial values in the AIZnMgCuScZr alloys than in AlZnMgCu alloys $(\Delta \mathrm{HV} 0.5 \approx 20)$ were probably caused by presence of Sc, Zr-containing particles and/or by higher content of addition in the AlZnMgCuScZr alloy.

- $\quad$ One exothermic process was observed in DSC curves of the alloys studied with maximum at $\sim 195^{\circ} \mathrm{C}$ at heating rate of $1 \mathrm{~K} / \mathrm{min}$. The activation energy was calculated as $\sim 100 \mathrm{~kJ} / \mathrm{mol}$ and TTT diagram of this process was done. Three positive stages at spectra derived with maxima at $\sim 110^{\circ} \mathrm{C}, \sim 180^{\circ} \mathrm{C}$ and $\sim 250^{\circ} \mathrm{C}$ were observed in the alloys studied. Exothermic process in DSC curves corresponds to IIpositive stage at spectra derived.

- The first relative resistivity decreases and minor I-stage at spectrum curves with maxima at $\sim 110{ }^{\circ} \mathrm{C}$ are caused by the dissolution of GP zones and/or clusters. The II-stage at spectrum curves with maxima at $\sim 180^{\circ} \mathrm{C}$, exothermic process in DSC curves (with maximum at $\sim 195^{\circ} \mathrm{C}$ at heating rate $1 \mathrm{~K} / \mathrm{min}$ in HR10 alloys) together with III-stage at spectrum curves with maxima at $\sim 250{ }^{\circ} \mathrm{C}$ are caused by combination of precipitation of $T$ phase and/or precipitation and/or coarsening of $S$ phase.

- After annealing up to $360^{\circ} \mathrm{C}$ secondary $\mathrm{Al}_{3}(\mathrm{Sc}, \mathrm{Zr}$ ) particles in the $\mathrm{AlZnMgCuScZr} \mathrm{HR}$ alloys caused hardening effect $\left(\triangle \mathrm{HV} 0.5 \approx 20-30\right.$ ). These particles probably precipitate during annealing at $300^{\circ} \mathrm{C} / 60$ min before/during hot deformation in the AlZnMgCuScZr alloys, too.

\section{ACKNOWLEDGEMENTS}

This work was supported by The Czech Science Foundation (GACR, project no. 17-17139S). VK acknowledges support by the Charles University, project GA UK No. 614119 and project SVV-2017260449 (Specific Academic Research Projects). PH acknowledges financial support by ERDF under the project CZ.02.1.01/0.0/0.0/15_003/0000485.

\section{REFERENCES}

[1] TOROPOVA, L.S., ESKIN, D.G., KHARAKTEROVA, M.L., DOBATKINA, T.V. Advanced aluminum alloys containing scandium - structure and properties. Amsterdam: Gordon and Breach Science Publisher, 1998. ISBN 90-5699-089-6.

[2] DURSUN, T., SOUTIS, C. Recent developments in advanced aircraft aluminium alloys. Materials and Design. 2014, vol. 56, pp. 862-871. DOI:10.1016/j.matdes.2013.12.002

[3] VAKHROMOV, R.O., ANTIPOV, V.V., TKACHENKO, E.A. Research and development of high-strength of AlZnMgCu alloys. In 13th International Conference on Aluminum Alloys, 2012, pp. 1514-1520. DOI: 10.1002/9781118495292.ch228 
[4] ROMETSCH, P. A., ZHANG, Y., KNIGHT, S. Heat treatment of 7xxx series aluminium alloys - Some recent developments. Trans Nonferrous Met Soc China. 2014, vol. 24, pp. 2003-2017. DOI:10.1016/S10036326(14)63306-9

[5] MOSTAFOPOOR, S., MALEKAN, M., EMAMY, M. Thermal analysis study on the grain refinement of Al-15Zn2.5Mg-2.5Cu alloy. J Therm Anal Calorim. 2017, vol. 127, pp. 1941-1952. DOI:10.1007/s10973-016-5737-7

[6] ZHANG, M., LIU, T., HE, CH., DING, J., LIU, E., SHI CH., ZHAO N. Evolution of microstructure and properties of Al-Zn-Mg-Cu-Sc-Zr alloy during aging treatment. J Alloy Compd. 2016, vol. 648, pp. 946-951. DOI: 10.1016/j.jallcom.2015.10.296.

[7] YANG, X.B., CHEN, J.H., LIU, J.Z., QIN, F., XIE, J., WU, C.L. A high-strength AIZnMg alloy hardened by the Tphase precipitates. J Alloy Compd. 2014, vol. 610, pp. 69-73. DOI: 10.1016/j.jallcom.2014.04.185.

[8] FENG, CH., SHOU, W., LIU, H., YI, D., FENG, Y. Microstructure and mechanical properties of high strength AlZn-Mg-Cu alloys used for oil drill pipes. Trans Nonferrous Met Soc China. 2015, vol. 25, pp. 3515-3522. DOI: 10.1016/S1003-6326(15)63994-2.

[9] AFIFY, N., GABER, A., ABBADY, G. Fine scale precipitates in Al-Mg-Zn alloys after various aging temperatures. Mater Sci App. 2011, no. 2, pp. 427-434. DOI: 10.4236/msa.2011.25056

[10] ZHOU, S, ZHANG, Z, Li, M., PAN, D, SU, H., DU, X., LI, P., WU Y. Effect of Sc on microstructure and mechanical properties of as-cast Al-Mg alloys. Mater Design. 2016. DOI: 10.1016/j.matdes.2015.10.132.

[11] VLACH, M., ČíŽEK, J., SMOLA, B., MELIKHOVA, O., VLČEK, M., KODETOVÁ, V., KUDRNOVÁ, H., HRUŠKA, $\mathrm{P}$. Heat treatment and age hardening of $\mathrm{Al}-\mathrm{Si}-\mathrm{Mg}-\mathrm{Mn}$ commercial alloy with addition of Sc and $\mathrm{Zr}$. Mater Charact. 2017. DOI: 10.1016/j.matchar.2017.04.017.

[12] SHI, Y., PAN, Q., LI, M., HUANG, X., LI, B. Effect of Sc and Zr additions on corrosion behaviour of Al-Zn-Mg-Cu alloys. J Alloy Compd. 2014. DOI: 10.1016/j.jmst.2016.12.003.

[13] KODETOVÁ, V., VLACH, M., KUDRNOVÁ, H., MÁLEK, J., CIESLAR, M., BAJTOŠOVÁ, L., KEKULE, T., HARCUBA, P., LUKÁČ, F., LEIBNER, M. Phase transformations in commercial cold-rolled Al-Zn-Mg-Cu alloys with Sc and Zr addition. J Therm Anal Calorim. 2020. DOI: 10.1007/s10973-020-09862-x

[14] VLACH, M., ČížEK, J., KODETOVÁ, V., LEIBNER, M., CIESLAR, M., HARCUBA, P., BAJTOŠOVÁ, L., KUDRNOVÁ, H., VLASÁK, T., ČERNOŠKOVÁ, E., KUTÁLEK, P., NEUBERT, V. Phase transformations in novel hot-deformed Al-Zn-Mg-Cu-Si-Mn-Fe(-Sc-Zr) alloys. Mater Design. 2020. DOI: 10.1016/j.matdes.2020.108821

[15] VLACH, M., ČÍŽEK, J., KODETOVÁ, V., KEKULE, T., LUKÁČ, F., CIESLAR, M., KUDRNOVÁ, H., BAJTOŠOVÁ, L., LEIBNER, M., HARCUBA, P., MÁLEK, J., NEUBERT, V. Annealing effects in cast commercial aluminium AlMg-Zn-Cu(-Sc-Zr) alloys. Met Mater Int. 2019. DOI: 10.1007/s12540-019-00499-6

[16] STARINK, M. J. The determination of activation energy from linear heating rate experiments: a comparison of the accuracy of isoconversion methods. Thermochimica Acta. 2003, vol. 404, pp. 163-176. DOI: 10.1016/S00406031(03)00144-8

[17] LANG, P., WOJCIK, T., POVODEN-KARADENIZ, E., FALAHA, A., KOZESCHNIK, E. Thermokinetic prediction of metastable and stable phase precipitation in Al-Zn-Mg series aluminium alloys during non-isothermal DSC analysis, J Alloys Compd., 2014, vol. 609, pp. 129. DOI: 10.1016/j.jallcom.2014.04.119.

[18] WEST, R. N. Positron studies of condensed matter. Adv Phys. 1973, vol. 22, pp. 263-383 DOI:10.1080/00018737300101299

[19] PRASANTA, K.R., GHOSH, M.M., GHOSH, K.S. Microstructural, mechanical and electrochemical behaviour of a 7017 Al-Zn-Mg alloy of different tempers. Mater Charact. 2015, 104, pp. 49-60. DOI: 10.1016/j.matchar.2015.03.025.

[20] ANTONIONE, C., MARINO, F., RIONITINO, G., ABIS, S., RUSSO, E. An evaluation of AA 7012 microstructure by differential scanning calorimetry. Mater Chem Phys. 1988, vol. 20, pp.13-25. DOI: 10.1016/0254-0584(88)900557.

[21] OLAFSON, P., SANDSTROM, R., KARLSSON, A.J. Comparison of experimental, calculated and observed values for electrical and thermal conductivity of aluminium alloys. J Mater Sci. 1997, vol. 32, pp. 4383-4390. DOI:10.1023/A:1018680024876.

[22] CHEMINGUI, M., AMEUR, R., OPTASANU, V., KHITOUNI, M. DSC analysis of phase transformations during precipitation hardening in AlZnMg alloy (7072). J Thermal Anal Calorim. 2019, vol. 136, pp. 1887-1894. DOI:10.1007/s10973-018-7856-9. 